Communications concerning membership in the African studies Association should be addressed to the Bxecutive Secretary, African studies Assoc1ation, 218 shiffman humanities Center, Brandeis University, Waltham, Massachusetts 0154 . Annual membership subscription rates are as follows: for Fellows, \$20.00; for Fellows (overseas), \$12.00 (55); for Assoclates, $\$ 12.00$; and for student Associates, $\$ 8.00(53 / 7)$.

Bubscription correspondence and chenge of address notice should be sent to Mrs. Janet Fichacls, African Studies Association, 218 shtefman Humanties Center, Brandels University, Waltham, Massachusetts 02154. Institutional subscription rates are $\$ 20.00$ (18/7) per year. Price of a single copy is $\$ .00$ (53). Allow four weeks for change of address. Subscribers are requested to notify their local postmaster and Mrs. Michaels in advance of change, giving both old and new addresses. In the Untted states please Include ZIP code.

Information for cantributors to the Review: Contributions are welcome whether or not the author 18 a member of the Assocletion. Manuscripts should be typed on one side of sheet only, double-spaced, and with ample margins for editorial merking. The orlginal and, if possible, one carbon copy should be aubmitted. Authors are advised to include footnote material in the text wherever passible. Footnotes shourd be mumbered cansecutively throughout the article but should not include bibllographical references. These should be incorporated within the text in parentheses with the author's last name, date of publication, and speciflc pages. An end bibllography with entries arranged by authors' last names should 11 st the complete references and Inclusive pages for articles. Articles may be 1 lluatrated with line drawings and maps, classified as figures, to be submitted in final form (except for size). Tables should be carefully prepared and should replace text, not duplicate $1 t$.

Book reviews, to be sent to the Book Revlew Bditor, carry no footnotes and "References C1ted" but incorporate bibllographical references and notes within the text. Please include complete information on the reviewed book (title, sub-title, author, publisher, place and date of publication, number of pages and plates, addenda, price). Short papers (up to 12 minuscript pages) may be submitted for the Brief Communications section. For detail. of form and style, consult a recent Review. Contributors of articles recelve ten reprints with covers.

All editorial correspondence and manuscripts, with the exception of book reviewa, should be sent to John P. Henderson, African studies Center, Michigan State University, Bast Lansing, Michigan 48823. Manuscripta should be recelved no later than January 15, June 15, and september 15 respectively. 


\section{Growth and Development of the Nigerian Economy}

EDITED BY

Carl Eicher

\section{Carl Liedholm}

The volume contains 21 chapters, of which 13 are original contributions from internationally known Africanists. The volume presents an excellent overview of Nigeria's social, economic, and political development from the Colonial period to Reconstruction in the early 1970 's.

$\$ 10.00$

\section{PART I. THE COLONIAL PERIOD}

The Dynamics of Long-Term Agricultural Development in Nigeria. Carl Eicher

Cocoa and Economic Development in West. ern Nigeria. Sarn Berry

The Origins of the Groundnut Trade in Northern Nigeria. Jan Hogendorn

The Influence of Colonial Policy on the Growth and Development of Nigeria's Industrial Sector. Carl Liedholm

\section{PART II. FROM REGIONALISM TO THE FIRST PLAN}

Structural Change in the Nigerian Economy, 1950-1960. Sara Berry and Carl Liedholm An Analysis of Nigerian Government Expenditure Patterns: 1950-1962. Charles Nixon

The Fiscal Role of the Marketing Boards in Nigerian Economic Development, 1947-1961. Gerald Helleiner

The Role of the Marketing Boards in the Political Evolution of Nigeria. Charles Nixon

The Niger Agricultural Project: An Experiment in African Development. K. D. S. Baldwin

Investment in Education. (The Ashby Report)
PART III. PLANNING AND

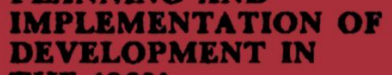

Social Factors in Economic Planning with Special Reference to Nigeria. W. F. Stolper Comprehensive Economic Planning in Nigeria. Lyle M. Hansen

Issues in Agricultural Policy During the 1962-1968 Nigerian Development Plan. Jerome Wells

Contractor Finance and Supplier Credit in Economic Growth. A. A. Ayida

New Sources of Growth in a Stagnant Smallholder Fconomy: The Oil Palm Rehabilitation Scheme. Malcolm Purvis

Nigerian Entrepreneurship in Industry. John

R. Harris

PART IV. PROBLEMS AND PROSPECTS FOR THE NIGERIAN ECONOMY IN THE 1970'.

Economic Growth and Political Instability in Nigeria: On Growing Together Again. W. F. Stolper

Nigerian Petroleum: Implication for MediumTerm Planning. Scott R. Pearson

Policy for Nigerian Agricultural Development in the 1970's. Carl K. Eicher and Glenn L. Johnson

From Ashby to Reconstruction: Manpower and Education in Nigeria. Frederick $\mathbf{H}$. Harbison

Towards a West Alrican Common Market. H. M. A. Onitiri 